\title{
Recurrent small bowel obstruction caused by Burkitt lymphoma in an elderly man: a case report and review of the literature
}

\author{
Saro Kasparian ${ }^{1 *}$, Ethan Burns ${ }^{1}$, Ahmed Shehabeldin², Melina Awar $^{1}$ and Sai Ravi Pingali ${ }^{1,3}$
}

\begin{abstract}
Background: Acute small bowel obstruction is a common surgical emergency usually caused by abdominal adhesions, followed by intraluminal tumors from metastatic disease. Although lymphomas have been known to cause bowel obstruction, Burkitt lymphoma is seldom reported to induce an obstruction in the adult population.

Case presentation: A 78-year-old Hispanic man with a history of abdominal interventions presented to our hospital with abdominal pain. Computed tomography revealed a partial small bowel obstruction attributed to local inflammation or adhesions. Medical management with bowel rest and nasogastric decompression resulted in resolution of symptoms and quick discharge. He returned 2 days later with worsening abdominal pain. Repeat imaging showed progression of the partial small bowel obstruction, but with an additional 1.6-cm nodular density abutting the anterior aspect of the gastric antrum and lobulated anterior gastric antral wall thickening. He was taken to the operating room, where several masses were found. Intraoperative frozen sections were consistent with lymphoma, and pathology later revealed Burkitt lymphoma. Disease was found on both sides of the diaphragm by positron emission tomography. After the initial resection and adjuvant chemotherapy, the patient is alive and well about 14 months after resection.
\end{abstract}

Conclusions: Small bowel obstruction is uncommonly due to Burkitt lymphoma in the geriatric population and is more frequently seen in the pediatric and young adult populations. Burkitt lymphoma is very aggressive with rapid cell turnover leading to significant morbidity. The rapid recurrence of an acute abdominal process should prompt an investigation for a more sinister cause such as malignancy.

Keywords: Sporadic Burkitt lymphoma, Small bowel obstruction, Recurrent

\section{Introduction}

Acute small bowel obstruction (SBO) is a common surgical emergency. Approximately 300,000 patients are hospitalized annually for mechanical SBO [1, 2], and this comprises $12-16 \%$ of hospital admissions for abdominal pain in the United States. The most significant risk factors for an SBO are abdominal adhesions due to prior abdominal surgeries [3]. Intraluminal tumors are the

\footnotetext{
* Correspondence: sarokasparianmd@gmail.com

'Department of Internal Medicine, Houston Methodist Hospital, Houston, TX 77030, USA

Full list of author information is available at the end of the article
}

second most common cause of SBO, the majority of which are due to metastatic disease [4]. Lymphomas make up an estimated $24 \%$ of neoplasia-induced bowel obstruction [5], with few cases attributed to Burkitt lymphoma (BL) in the adult population. The present case report highlights the rare presentation and clinical implications of recurrent SBO due to sporadic BL.

\section{Case presentation}

A 78-year-old Hispanic man presented to the emergency department (ED) of our hospital with abdominal pain accompanied by nausea and bilious emesis. His history

\section{$\triangle B M C$}

(c) The Author(s). 2020 Open Access This article is licensed under a Creative Commons Attribution 4.0 International License, which permits use, sharing, adaptation, distribution and reproduction in any medium or format, as long as you give appropriate credit to the original author(s) and the source, provide a link to the Creative Commons licence, and indicate if changes were made. The images or other third party material in this article are included in the article's Creative Commons licence, unless indicated otherwise in a credit line to the material. If material is not included in the article's Creative Commons licence and your intended use is not permitted by statutory regulation or exceeds the permitted use, you will need to obtain permission directly from the copyright holder. To view a copy of this licence, visit http://creativecommons.org/licenses/by/4.0/ The Creative Commons Public Domain Dedication waiver (http://creativecommons.org/publicdomain/zero/1.0/) applies to the data made available in this article, unless otherwise stated in a credit line to the data. 
was significant for an open appendectomy, laparoscopic cholecystectomy, and umbilical hernia repair. He had no significant family history and did not smoke, drink alcohol, or use illicit substances. The patient denied fever or night sweats but complained of anorexia and unintentional weight loss in the month leading up to admission. His physical examination revealed normal bowel sounds, no tympani on percussion, no palpable masses, no hepatosplenomegaly, no fluid wave, and a soft but diffusely tender and distended abdomen. Computed tomography (CT) of his abdomen and pelvis with oral and intravenous contrast revealed small bowel distention and a short segment of bowel wall thickening with enhancement in the right lower quadrant consistent with a partial SBO, likely arising from either local inflammation or adhesion (Fig. 1a). He was treated medically with bowel rest and decompression with nasogastric tube placement. The patient reported significant relief shortly after decompression, with complete resolution within 48 hours. His diet was advanced, and he was discharged to home with close outpatient follow-up.

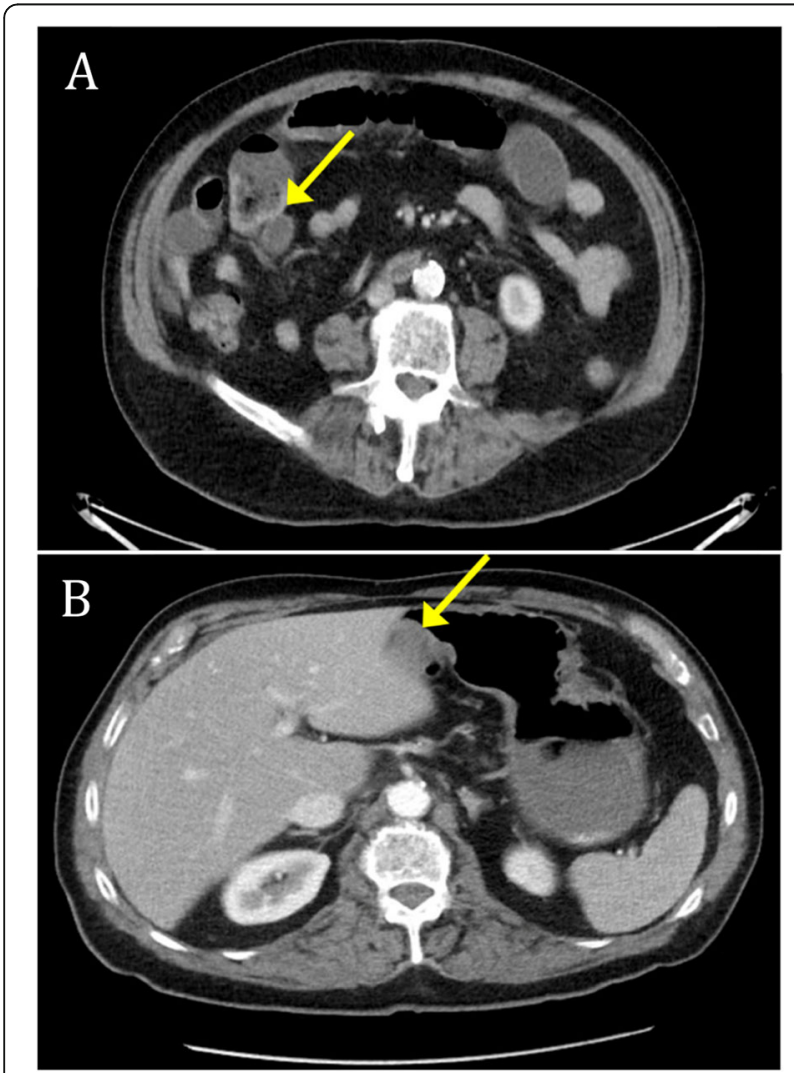

Fig. 1 Computed tomography (CT) of the abdomen. Abdominal CT scans of first admission compared with second admission. a Partial bowel obstruction noted on first admission with transition point (arrow). b Nodular mural thickening of the anterior aspect of the gastric antrum (arrow)
He returned to our ED 2 days after discharge with recurrence of abdominal pain, distention, nausea, and bilious vomiting. Repeat $\mathrm{CT}$ of his abdomen and pelvis with oral and intravenous contrast showed a moderate increase in the small bowel distention with a transition point in the left middle abdomen consistent with moderate progression of the partial SBO. CT also revealed a $1.6-\mathrm{cm}$ nodular density abutting the anterior aspect of

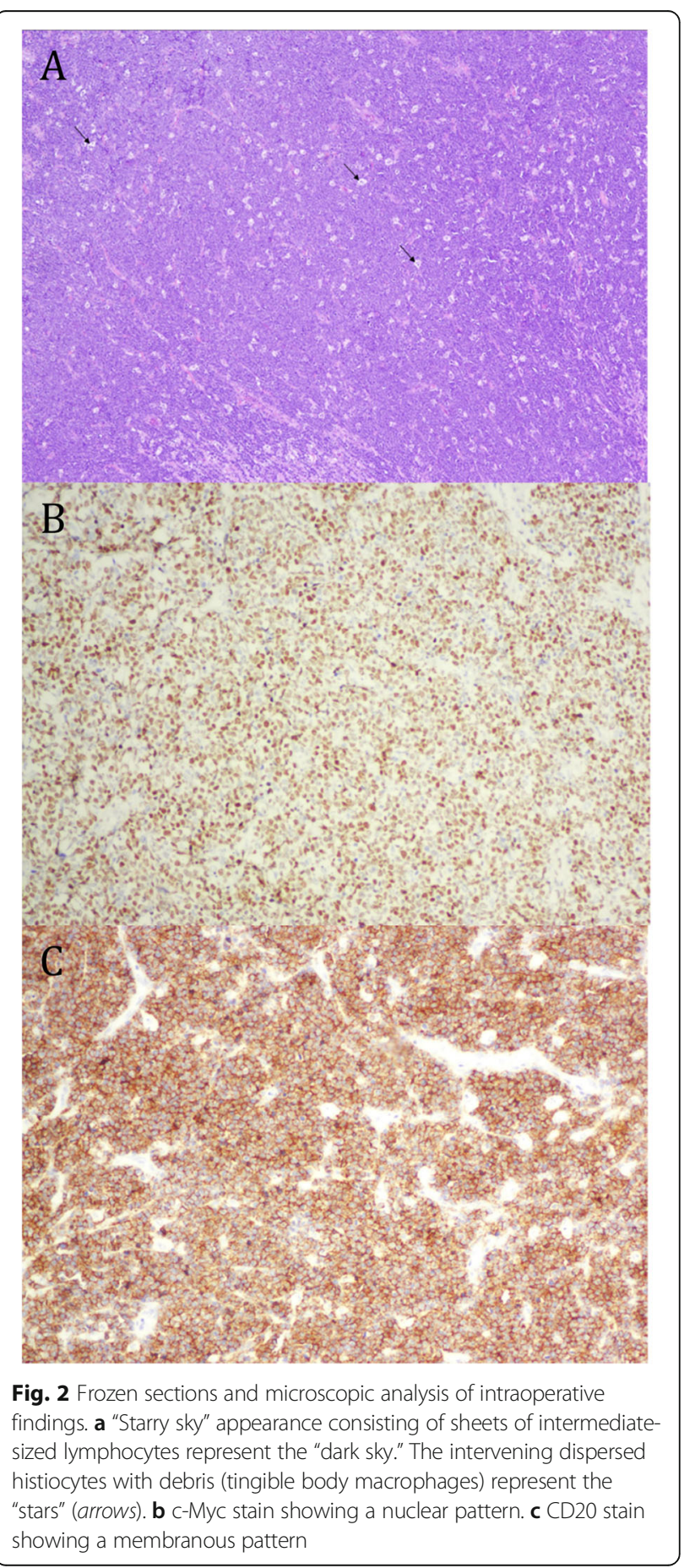


the gastric antrum and lobulated anterior gastric antral wall thickening concerning for atypical gastritis or a gastric tumor (Fig. 1b). Because of an unsuccessful trial of decompression, the patient was taken to the operating room for adhesiolysis and possible bowel resection.

Intraoperative findings included a completely obstructive mass within the ileum, a partial obstruction by two masses within the jejunum, and a nonobstructive gastric antral mass. He underwent two small bowel resections with excision of the small bowel tumors. Intraoperative frozen section analysis of the small bowel tumors was consistent with lymphoma. The tissue sample was positive for cluster of differentiation (CD)20, paired box protein 5 (PAX5), B-cell lymphoma protein (BCL)-6, and cellular myelocytomatosis (c-Myc), and it was negative for BCL-2, CD3, and CD5 (Fig. 2). The result of Epstein-Barr virus polymerase chain reaction testing was also positive. Flow cytometry showed an abnormal B-cell population positive for CD10, CD19, CD20, CD22, CD38, and CD45 with kappa-light-chain restriction, but it was negative for T-cell markers, CD5, and lambda light chain (Fig. 3). The final pathology was consistent with BL. He underwent a bone marrow biopsy and aspirate that was negative for lymphoma. Positron emission tomography (PET) demonstrated active disease on both sides of the diaphragm, including adenopathy in the chest, gastric antrum, and the greater gastric curvature, consistent with a stage III BL (Fig. 4a).

After postoperative recovery, the patient was initiated on six cycles of adjuvant combination chemotherapy with dose-adjusted etoposide, prednisone, vincristine, cyclophosphamide, hydroxydaunorubicin, and rituximab (DA-EPOCHR), as well as intrathecal (IT) methotrexate for central nervous system (CNS) prophylaxis. Overall, he tolerated the chemotherapy regimen well, except for a subsequent $\mathrm{SBO}$ during the sixth cycle that was managed conservatively. A post-treatment PET scan showed complete remission (Fig. 4b), and the patient is still being followed 14 months after initial resection.

\section{Discussion}

We present a unique case of a recurrent $\mathrm{SBO}$ due to $\mathrm{BL}$ in an elderly man, an uncommon presentation of an uncommon diagnosis in the elderly. BL cells are mature Bcells arising from postgerminal centers of lymph nodes. They generally have a high proliferative index (Ki67) approaching $100 \%$, and their typical immunophenotype expresses CD19, CD20, CD22, CD45, CD79, and germinal center markers CD10 and BCL6 [6]. Their high rate of proliferation is mediated by the activation of the MYC oncogene on chromosome 8 via translocation, most commonly to the immunoglobulin heavy chain locus found on chromosome $14 \mathrm{t}(8: 14)$ [7]. The translocation is thought to occur during immunoglobulin class switching and somatic hypermutation in B-cells causing double-stranded DNA breaks [8]. This leads to a constitutive overexpression of the MYC protein, resulting in unregulated cell proliferation. MYC is a transcription factor involved in regulating approximately $15 \%$ of all genes, particularly those involved in cell growth [9]. On microscopic examination, these mutations lead to the development of sheets of intermediate-sized lymphocytes and dispersed histiocytes, classically referred to as the "starry sky" pattern (Fig. 2).

$\mathrm{BL}$ is a rare, highly aggressive, and rapidly dividing form of non-Hodgkin lymphoma (NHL) that accounts for $<1 \%$ of adult NHL in the United States [10]. Three forms of BL have been recognized: the endemic form, the immunodeficiencyassociated form, and the sporadic form. The endemic form comprises $30-50 \%$ of childhood cancers in equatorial Africa, with an approximate incidence of 3-6 cases per 100,000 children per year [11]. The immunodeficiency-associated variant is seen primarily in individuals with HIV infection
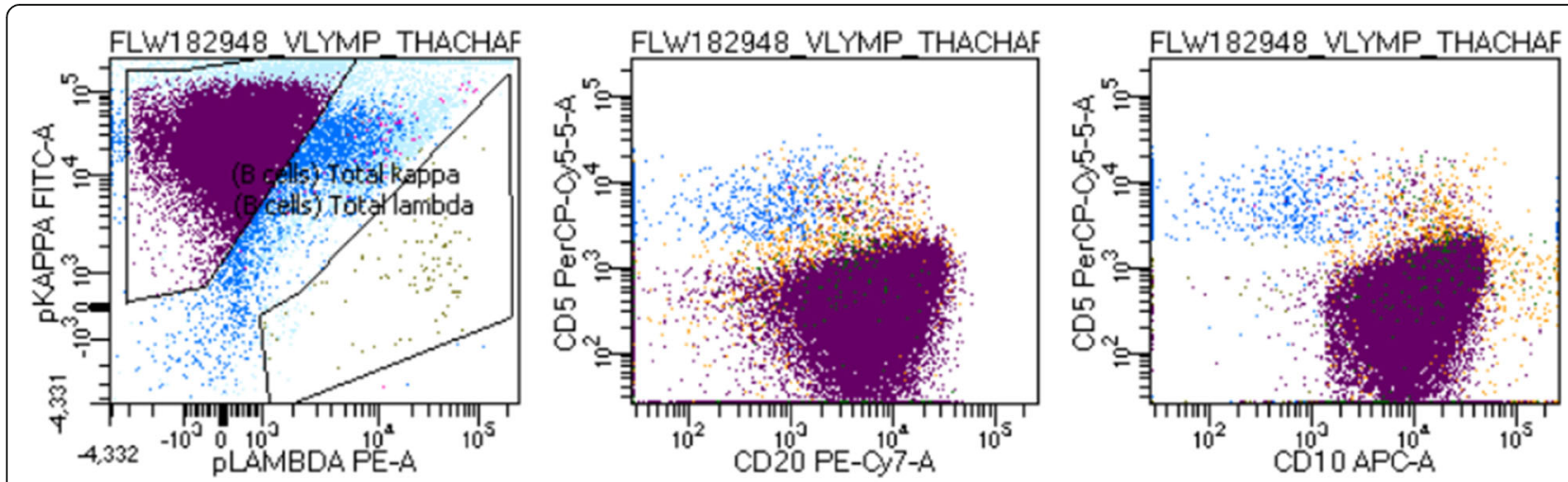

Fig. 3 Flow cytometry. Results of flow cytometry consistent with B-cell lymphoma, which is kappa-light chain restricted with expression of CD10 and lack of CD5 expression 


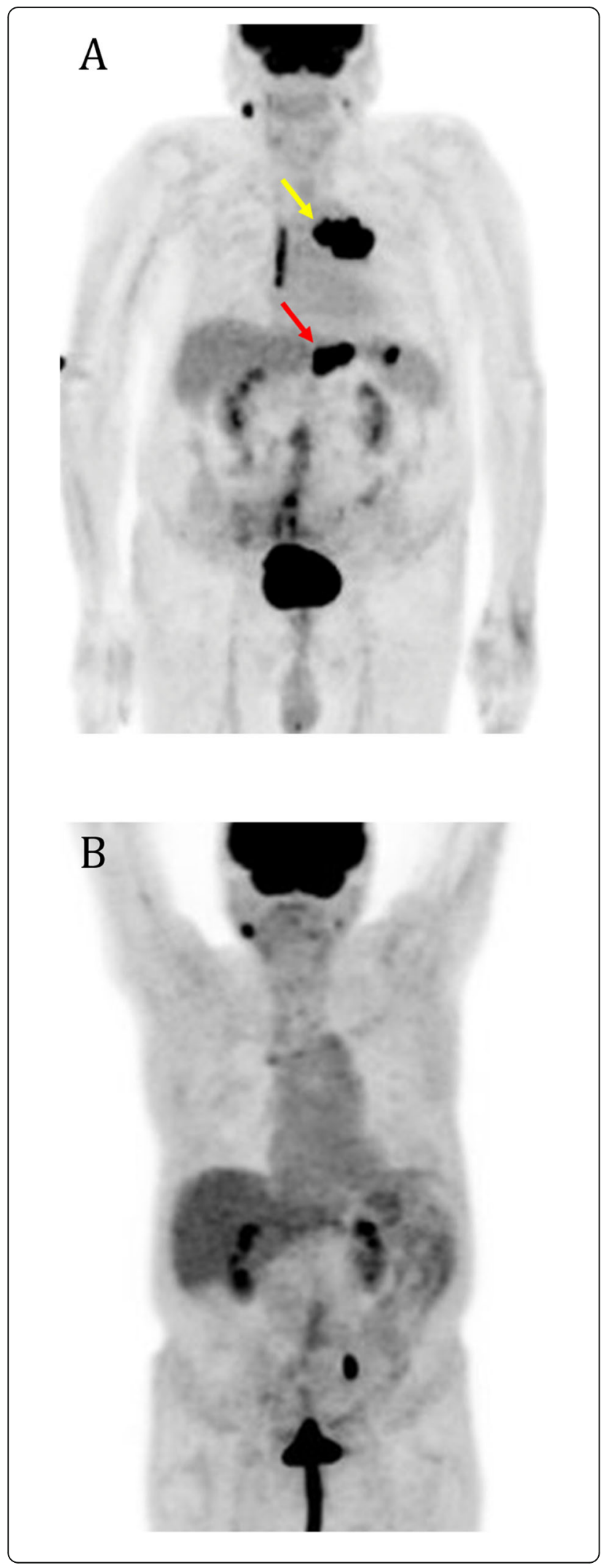

Fig. 4 Positron emission tomography (PET) scan. a Pretreatment PET with active lymphoma on both sides of the diaphragm, including chest adenopathy and multifocal gastric involvement in the abdomen. Yellow arrow: chest adenopathy with standardized uptake value (SUV) of 20.4. Red arrow: gastric antrum uptake with SUV of 14.1. b Post-treatment PET about 6 months after resection showing no definite evidence of lymphoma

counterintuitively with higher CD4 counts, and generally in the absence of opportunistic infections [12].

The sporadic form is commonly encountered in the United States and Europe, comprising 30\% of pediatric lymphomas, with a peak incidence at age 11 years [10]. In adults, BL is most prevalent in Caucasian males with a median age of 30 years and a male predominance [13, 14]. Sporadic BL often presents with bulky tumors in extranodal sites, frequently in the abdomen [15], but it is also seen in the kidney, pancreas, liver, spleen, breast, and ovaries and rarely the head and neck [15-17]. Symptoms of BL in the gastrointestinal tract can be nonspecific and include abdominal pain, nausea, and vomiting or can be more pronounced in the form of obstruction, acute appendicitis, or intussusception. These abdominal syndromes are more frequently reported in young adult and pediatric patients $[18,19]$. A review of the available literature suggests that abdominal syndromes as the initial presentation of BL are seldom reported in the elderly patient population. Furthermore, the presence of recurrent abdominal syndromes such as SBO as the initial presentation has not been reported outside of the young adult and pediatric populations (Table 1). To our knowledge, this is the first reported case of BL presenting as a recurrent SBO.

The prognosis for $\mathrm{BL}$ in the era of chemoimmunotherapy is generally age-dependent. Analysis of the Surveillance, Epidemiology, and End Results Program database showed that among those diagnosed between 2002 and 2008, 5-year survival decreased, depending on age, from $87 \%, 60 \%, 48 \%$, to $33 \%$ for ages $<20$ years, $20-39$ years, $40-59$ years, and $>59$ years, respectively [29]. In addition, poorer outcomes were seen in black patients and those with advanced disease [29].

$\mathrm{BL}$ is an aggressive cancer and requires prompt recognition and treatment to improve outcomes. Consensus on first-line therapy for BL is lacking, but combination chemotherapy along with CNS chemoprophylaxis is recommended. Ann Arbor or Murphy scales are used for staging, which is further classified as low or high risk on the basis of the bulk of disease, number of sites, and lactate dehydrogenase elevation [12]. The classic Magrath method [11] uses cyclophosphamide, vincristine, doxorubicin, and high-dose methotrexate, with IT methotrexate, alternating with ifosfamide, etoposide, and cytarabine-A (CODOX-M/IVAC) [30]. The modified 
Table 1 Literature review of adult Burkitt lymphoma with obstructive symptoms

\begin{tabular}{|c|c|c|c|c|c|c|c|c|}
\hline Author & $\begin{array}{l}\text { Age } \\
(\mathrm{yr})\end{array}$ & Sex & BL type & Presentation & $\begin{array}{l}\text { Abdominal } \\
\text { syndrome }\end{array}$ & $\begin{array}{l}\text { Syndrome } \\
\text { recurrence }\end{array}$ & Treatment regimen & Outcome \\
\hline $\begin{array}{l}\text { Fernandes } \\
\text { et al. [20] }\end{array}$ & 21 & Female & Sporadic & Abdominal pain & Intussusception & Yes & Resection alone & NR \\
\hline $\begin{array}{l}\text { Simson et al. } \\
\text { [21] }\end{array}$ & 22 & Female & Sporadic & $\begin{array}{l}\text { Persistent abdominal pain, } \\
\text { appendicitis }\end{array}$ & $\begin{array}{l}\text { Appendicitis then } \\
\text { intussusception }\end{array}$ & No & $\begin{array}{l}\text { Resection with adjuvant } \\
\text { chemotherapy }\end{array}$ & NR \\
\hline $\begin{array}{l}\text { Sharma et al. } \\
\text { [22] }\end{array}$ & 26 & Male & HIV & $\begin{array}{l}\text { Viral syndrome, abdominal } \\
\text { distention }\end{array}$ & Obstruction & No & $\begin{array}{l}\text { Resection then R-CODOX-M/ } \\
\text { IVAC }\end{array}$ & NR \\
\hline $\begin{array}{l}\text { Wetter et al. } \\
\text { [23] }\end{array}$ & 29 & Female & HIV & Abdominal pain & Intussusception & No & Resection & NR \\
\hline $\begin{array}{l}\text { Gupta et al. } \\
\text { [24] }\end{array}$ & 33 & Female & HIV & $\begin{array}{l}\text { Loose stool, abdominal } \\
\text { discomfort, nausea, obstructive } \\
\text { jaundice }\end{array}$ & $\begin{array}{l}\text { Obstructive } \\
\text { jaundice }\end{array}$ & No & CODOX-M/IVAC & $\begin{array}{l}\text { Complete } \\
\text { remission }\end{array}$ \\
\hline $\begin{array}{l}\text { Felix et al. } \\
{[25]}\end{array}$ & 34 & Male & NR & Abdominal pain & Intussusception & Yes & Resection & NR \\
\hline $\begin{array}{l}\text { Özant et al. } \\
\text { [26] }\end{array}$ & 37 & Female & Sporadic & $\begin{array}{l}\text { Abdominal pain, nausea, } \\
\text { vomiting }\end{array}$ & $\begin{array}{l}\text { Obstruction due } \\
\text { to } \\
\text { intussusception }\end{array}$ & No & Resection with hyperCVAD & $\begin{array}{l}\text { Complete } \\
\text { remission }\end{array}$ \\
\hline $\begin{array}{l}\text { Mizutani } \\
\text { et al. [27] }\end{array}$ & 38 & Male & NR & Abdominal pain & Obstruction & No & $\begin{array}{l}\text { Cyclophosphamide and } \\
\text { doxorubicin with R-CODOX- } \\
\text { M/IVAC }\end{array}$ & $\begin{array}{l}\text { Complete } \\
\text { remission }\end{array}$ \\
\hline $\begin{array}{l}\text { Zerwas et al. } \\
\text { [28] }\end{array}$ & 52 & Male & NR & $\begin{array}{l}\text { Abdominal pain, nausea, } \\
\text { vomiting }\end{array}$ & Intussusception & NR & Resection & NR \\
\hline $\begin{array}{l}\text { Kasparian } \\
\text { et al. [this } \\
\text { report] }\end{array}$ & 78 & Male & Sporadic & $\begin{array}{l}\text { Abdominal pain, nausea, } \\
\text { vomiting }\end{array}$ & Obstruction & Yes & Resection then DA-EPOCHR & $\begin{array}{l}\text { Complete } \\
\text { remission }\end{array}$ \\
\hline
\end{tabular}

This is the first reported case of $\mathrm{BL}$ presenting with recurrent $\mathrm{SBO}$ in the geriatric population

Abbreviations: DA-EPOCHR Dose-adjusted etoposide, prednisone, vincristine, cyclophosphamide, hydroxydaunorubicin, and rituximab, HIV Human immunodeficiency virus, hyperCVAD Cyclophosphamide, vincristine, doxorubicin, NR Not reported, (R) CODOX-M /IVAC (Rituximab) cyclophosphamide, vincristine, doxorubicin, and high-dose methotrexate, with intrathecal methotrexate, alternating with ifosfamide, etoposide, and cytarabine-A

Magrath method is preferred in older adults (median age 47 years) due to its better-tolerated toxicity profile, with $86 \%$ of patients achieving a complete response and $64 \%$ an event-free survival at 29 months [30]. In a phase II study, Evens et al. reported that the addition of rituximab combined with liposomal doxorubicin achieved an overall response rate of $100 \%$ with complete remission in $92 \%$. At 34-month median follow-up, the 2-year progression-free survival (PFS) and overall survival (OS) rates for all patients were $80 \%$ and $84 \%$, respectively (low-risk, both $100 \%$; high-risk, $76 \%$ and $81 \%$, respectively) [31]. Alternative first-line regimens recommended by the National Comprehensive Cancer Network include DA-EPOCHR and cyclophosphamide, vincristine, and doxorubicin (HyperCVAD). The PFS and OS in the EPOCH group were found to be $95 \%$ and $100 \%$, respectively, at median follow-up of 86 months [32], whereas the 36-month OS and PFS in the HyperCVAD group were $88 \%$ and $89 \%$, respectively [33]. CNS involvement is common in NHL, and most regimens employ some form of CNS prophylaxis, usually in the form of IT methotrexate and/or cytarabine, to prevent future CNS relapse [34]. Surgery and radiation therapy do not have routine roles in treatment of BL other than in the intervention of emergent abdominal syndromes.

\section{Conclusions}

SBOs are uncommonly due to sporadic BL in the adult populace. BL is seldom diagnosed in the geriatric population. This case illustrates the rapid growth and significant morbidity of sporadic BL presenting as recurrent SBO. The unexpected recurrence of an abdominal disease process should lead to the consideration of more aggressive pathologies such as intra-abdominal malignancies.

\section{Abbreviations}

BCL: B-cell lymphoma; BL: Burkitt lymphoma; CD: Cluster of differentiation; CMyc: Cellular myelocytomatosis; CNS: Central nervous system; CODOX-M/ IVAC: Cyclophosphamide, vincristine, doxorubicin, high-dose methotrexate, ifosfamide, etoposide, and cytarabine-A; CT: Computed tomography; DAEPOCHR: Dose-adjusted etoposide, prednisone, vincristine, cyclophosphamide, hydroxydaunorubicin, and rituximab; ED: Emergency department; HyperCVAD: Cyclophosphamide, vincristine, doxorubicin;

IT: Intrathecal; NHL: Non-Hodgkin lymphoma; OS: Overall survival; PAX 5: Paired box protein 5; PET: Positron emission tomography; PFS: Progressionfree survival; SBO: Small bowel obstruction

\section{Acknowledgements}

We thank the patient and his family for their cooperation.

\section{Authors' contributions}

SK provided substantial contributions to conception and design of the manuscript, acquisition of data, analysis and interpretation of data, drafting the article, revising it critically for important intellectual content, and final approval of the version to be published. EB provided substantial contributions to conception and design of the manuscript, acquisition of 
data, analysis and interpretation of data, drafting the article, revising it critically for important intellectual content, and final approval of the version to be published. AS obtained and annotated pathologic images and flow cytometric dot plots, provided substantial contributions to drafting the article, revising it critically for important intellectual content, and final approval of the version to be published. MA provided substantial contributions to conception and design of the manuscript, drafting the article, revising it critically for important intellectual content, and final approval of the version to be published. SRP provided substantial contributions to conception and design of the manuscript, drafting the article, revising it critically for important intellectual content, and final approval of the version to be published. All authors read and approved the final manuscript.

\section{Funding}

Not applicable.

\section{Availability of data and materials}

Not applicable.

\section{Ethics approval and consent to participate} Not applicable.

\section{Consent for publication}

Written informed consent was obtained from the patient for publication of this case report and any accompanying images. A copy of the written consent is available for review by the Editor-in-Chief of this journal.

\section{Competing interests}

The authors declare that they have no competing interests.

\section{Author details}

${ }^{1}$ Department of Internal Medicine, Houston Methodist Hospital, Houston, TX 77030, USA. ²Department of Pathology, Houston Methodist Hospital, Houston, TX 77030, USA. ${ }^{3}$ Division of Hematology and Oncology, Houston Methodist Hospital, Houston, TX 77030, USA.

Received: 1 June 2019 Accepted: 7 July 2020

Published online: 12 August 2020

\section{References}

1. Rami Reddy SR, Cappell MS. A systematic review of the clinical presentation, diagnosis, and treatment of small bowel obstruction. Curr Gastroenterol Rep. 2017;19(6):28.

2. Irvin TT. Abdominal pain: a surgical audit of 1190 emergency admissions. $\mathrm{Br}$ J Surg. 1989;76(11):1121-5.

3. Mullan CP, Siewert B, Eisenberg RL. Small bowel obstruction. AJR Am J Roentgenol. 2012;198(2):W105-17.

4. Kendrick ML. Partial small bowel obstruction: clinical issues and recent technical advances. Abdom Imaging. 2009;34(3):329-34.

5. Beltran MA, Cruces KS. Primary tumors of jejunum and ileum as a cause of intestinal obstruction: a case control study. Int J Surg. 2007;5(3):183-91.

6. Kelemen K, Braziel RM, Gatter K, Bakke TC, Olson S, Fan G. Immunophenotypic variations of Burkitt lymphoma. Am J Clin Pathol. 2010; 134(1):127-38.

7. Hecht JL, Aster JC. Molecular biology of Burkitt's lymphoma. J Clin Oncol. 2000;18(21):3707-21

8. Casulo C, Friedberg JW. Burkitt lymphoma - a rare but challenging lymphoma. Best Pract Res Clin Haematol. 2018;31(3):279-84.

9. Gearhart J, Pashos EE, Prasad MK. Pluripotency redux — advances in stemcell research. N Engl J Med. 2007;357(15):1469-72.

10. Morton LM, Wang SS, Devesa SS, Hartge P, Weisenburger DD, Linet MS. Lymphoma incidence patterns by WHO subtype in the United States, 19922001. Blood. 2006:107(1):265-76.

11. Magrath I. Epidemiology: clues to the pathogenesis of Burkitt lymphoma. $\mathrm{Br}$ J Haematol. 2012;156(6):744-56.

12. Guech-Ongey $M$, Simard EP, Anderson WF, et al. AIDS-related Burkitt lymphoma in the United States: what do age and CD4 lymphocyte patterns tell us about etiology and/or biology? Blood. 2010;116(25):5600-4.

13. Jacobson C, Lacasce A. How I treat Burkitt lymphoma in adults. Blood. 2014; 124(19):2913-20
14. Armitage JO, Weisenburger DD. New approach to classifying non-Hodgkin's lymphomas: clinical features of the major histologic subtypes. Non-Hodgkin's Lymphoma Classification Project. J Clin Oncol. 1998;16(8):2780-95.

15. Smith A, Howell D, Patmore R, Jack A, Roman E. Incidence of haematological malignancy by sub-type: a report from the Haematological Malignancy Research Network. Br J Cancer. 2011;105(11):1684-92.

16. Blum KA, Lozanski G, Byrd JC. Adult Burkitt leukemia and lymphoma. Blood. 2004;104(10):3009-20.

17. Storck K, Brandstetter M, Keller U, Knopf A. Clinical presentation and characteristics of lymphoma in the head and neck region. Head Face Med. 2019;15(1):1

18. Dunnick NR, Reaman GH, Head GL, Shawker TH, Ziegler JL. Radiographic manifestations of Burkitt's lymphoma in American patients. AJR Am J Roentgenol. 1979;132(1):1-6.

19. Derinkuyu BE, Boyunağa Ö, Öztunalı Ç, et al. Imaging features of Burkitt lymphoma in pediatric patients. Diagn Interv Radiol. 2016;22(1):95-100.

20. Fernandes $C$, Pinho R, Ribeiro I, et al. Recurrent cecocolic intussusception in a young woman. Gastroenterol Hepatol. 2015;38(10):586-8.

21. Simson R, Planner A, Alexander R. Adult Burkitt's lymphoma presenting as intussusception: first UK case report. Ann R Coll Surg Engl. 2017:99(7):e206-8.

22. Sharma P, Balasingham S, Stawiarski K, et al. Burkitt lymphoma as a lead point for jejunojejunal intussusception in a human immunodeficiency virus patient. Clin J Gastroenterol. 2017;10(4):342-50.

23. Wetter A, Schaudt A, Lehnert T, Schmidt-matthiesen A, Jacobi V, Vogl TJ. Small-bowel intussusception as a rare differential diagnosis in HIV-positive patients with acute abdominal pain. Eur Radiol. 2006;16(4):952-3.

24. Gupta N, Wright JG, Bowman CA. An unusual cause of acute obstructive jaundice in an HIV-infected patient. Int J STD AIDS. 2011;22(2):110-1.

25. Felix EL, Cohen MH, Bernstein AD, Schwartz JH. Adult intussusception; case report of recurrent intussusception and review of the literature. Am J Surg. 1976:131(6):758-61.

26. Özant A, Arslan K, Özçay N, Besim H. Adult multicentric burkitt lymphoma with bowel obstruction due to intussusception. Turk J Gastroenterol. 2018; 29(3):361-4

27. Mizutani M, Umino A, Taniguchi M, Tamaki S, Tanigawa M, Tsuji K. Primary small intestinal Burkitt lymphoma treated with rituximab-combined CODOXM/IVAC therapy without surgical resection. Gan To Kagaku Ryoho. 2013; 40(9):1229-32.

28. Zerwas E, Kemper-martin A, Comes A. A case report of adult colonic intussusception. J La State Med Soc. 2008;160(2):102-3. 105.

29. Costa LJ, Xavier AC, Wahlquist AE, Hill EG. Trends in survival of patients with Burkitt lymphoma/leukemia in the USA: an analysis of 3691 cases. Blood. 2013;121(24):4861-6.

30. Barnes JA, Lacasce AS, Feng $Y$, et al. Evaluation of the addition of rituximab to CODOX-M/IVAC for Burkitt's lymphoma: a retrospective analysis. Ann Oncol. 2011;22(8):1859-64.

31. Evens AM, Carson KR, Kolesar J, et al. A multicenter phase II study incorporating high-dose rituximab and liposomal doxorubicin into the CODOX-M/IVAC regimen for untreated Burkitt's lymphoma. Ann Oncol. 2013:24(12):3076-81.

32. Dunleavy K, Pittaluga S, Shovlin M, et al. Low-intensity therapy in adults with Burkitt's lymphoma. N Engl J Med. 2013;369(20):1915-25.

33. Thomas DA, Faderl S, O'Brien S, et al. Chemoimmunotherapy with hyperCVAD plus rituximab for the treatment of adult Burkitt and Burkitt-type lymphoma or acute lymphoblastic leukemia. Cancer. 2006;106(7):1569-80.

34. Hill QA, Owen RG. CNS prophylaxis in lymphoma: who to target and what therapy to use. Blood Rev. 2006;20(6):319-32.

\section{Publisher's Note}

Springer Nature remains neutral with regard to jurisdictional claims in published maps and institutional affiliations. 